\title{
Trigonalidae (Hymenoptera) from cacao agroforestry systems in northeastern Brazil, with two new species of Trigonalys Westwood
}

\author{
Bernardo F. Santos ${ }^{1, \dagger}$, Alexandre P. Aguiar ${ }^{2, \ddagger}$, Anazélia M. Tedesco ${ }^{3, \S}$ \\ I Universidade Federal do Espírito Santo, Depto de Ciências Biológicas, Av. Fernando Ferrari, s/n - Goiabeiras, \\ Vitória, ES, 29075-010, Brazil \\ † urn:lsid:zoobank.org:author:9C1440DE-0C44-4F08-A312-2D1220A73E57 \\ † urn:lsid:zoobank.org:author:6CA248DA-56F5-45C3-9642-5B7B1F2A617A \\ § urn:lsid:zoobank.org:author:2991B785-A9E3-4776-B7E9-D1BFD0085EA0 \\ Corresponding author: Bernardo Santos (bernardofsantos@gmail.com) \\ Academic editor: W. Pulawski | Received 16 July 2011 | Accepted 16 February 2012 | Published 23 March 2012 \\ urn:lsid:zoobank.org:pub:55222C6B-9348-40E1-A495-04653889F633 \\ Citation: Santos BF, Aguiar AP, Tedesco AM (2012) Trigonalidae (Hymenoptera) from cacao agroforestry systems in \\ northeastern Brazil, with two new species of Trigonalys Westwood. Journal of Hymenoptera Research 25: 19-34. doi: \\ 10.3897/JHR.25.1810
}

\begin{abstract}
A survey of Trigonalidae from cacao (Theobroma cacao L.) agroforestry systems in southern Bahia, northeastern Brazil, is conducted. A total of 65 specimens were studied, and three species are recognized. Trigonalys melanoleuca Westwood is diagnosed and illustrated. Two new species are described and illustrated. Trigonalys erythrocephala sp. $\mathbf{n}$. has most of head reddish brown; metasomal armature in sternum III conspicuous, Y-shaped; supra-antennal elevation conspicuous; hind coxa with sharp lateral angles, its dorsomesal portion strigate; legs entirely dark brown; and fore wing lightly infuscate, darker towards anterior margin. Trigonalys gotica sp. $\mathbf{n}$. with body blackish or dark brown and has pale yellow marks; mesopleuron with an oblique mark; female armature absent; frons and vertex punctate-areolate; supra-antennal elevation subtle; propodeal foramen $\mathrm{V}$-shaped; and fore wing vein $\mathrm{M}$ arising distinctly basad to $1 \mathrm{cu}-\mathrm{a}$.
\end{abstract}

\section{Keywords}

Hyperparasitoid, Trigonalyidae, Trigonaloidea, Malaise

Copyright Bernardo F. Santos et al. This is an open access article distributed under the terms of the Creative Commons Attribution License 3.0 (CC-BY), which permits unrestricted use, distribution, and reproduction in any medium, provided the original author and source are credited. 


\section{Introduction}

Trigonalidae (Hymenoptera, Trigonaloidea) are a remarkable group of parasitoid wasps, with a unique biology (Carmean 1991) and a persistently elusive phylogenetic placement within Hymenoptera (Sharkey 2007). Species of this family are usually considered to be rare or difficult to collect (e.g., Carmean and Kimsey 1998), and most collections worldwide hold only a few specimens. As far as we know, there are no published records of Trigonalidae associated with agricultural systems, even considering specific sampling programs in, e.g., coffee (Perioto et al. 2004, Santos and PérezMaluf 2010), cotton (Perioto et al. 2002a), soybean (Perioto et al. 2002b), Eucalyptus (Dall'Oglio et al. 2000), and crop rotation (Souza et al. 2006).

In Brazil, cacao (Theobroma cacao L., Sterculiaceae) is a major commodity, mostly cultivated in agroforestry systems, using planted shade trees or thinned native forest, the so-called cabruca, usually intermingled with untouched forest remnants (Vinha et al. 1983). These systems are both less vulnerable to pest outbreaks and important for conservation of natural habitats (see Nakayama et al. 2008 for an outline). Preliminary assessments of the parasitoid fauna in cacao agroforestry systems were performed by Sperber et al. (2004) and Nakayama et al. (2008), but no specimens of Trigonalidae were collected in those studies.

Here, we present a study of the Trigonalidae from cacao agroforestry systems, and describe two new species of Trigonalys Westwood. Very little is known on the biology of this genus. There are two records of species of Trigonalys reared from species of Lepidoptera (Schultz 1910, Carmean and Kimsey 1998). Considering the predominantly hyperparasitoid way of life of the Trigonalidae, the Trigonalys species may be hyperparasitoids, and the Lepidoptera their primary hosts.

\section{Materials and methods}

A total of 128 collecting events were conducted in several private properties, in 19 municipalities in southern Bahia, northeastern Brazil, during 2002-2003 and 20062007. These collecting trips were organized and conducted by Julia M. O. Valverde, Kazuiyuki Nakayama, and others at Comissão de Aperfeiçoamento da Lavoura Cacaueira (CEPLAC/Brazil). On each collecting trip in 2002-2003, eight Townes' style Malaise traps (Townes 1972) were set to collect continuously for seven days. In 2006-2007, 18 collecting trips were conducted, each using two Malaise traps for seven days. All traps were set in areas of cacao agroforestry systems. Most of the collecting effort was concentrated in the humid season (November to March), but some areas were also sampled during the dry season (April to August). The total sampling effort amounts to 6,412 trap-days.

All observations, including details of sculpturing and color, were made using a Leica M80 stereomicroscope with 10x oculars, and a 9W fluorescent lighting bulb. Measurements were taken with a $10 \mathrm{~mm}$ ocular grid with 100 divisions, attached to a 
Leica MZ12.5. Images were generated using the extended-focus system by EntoVision (GTVision, Hagerstown, Maryland), including a Leica Z16 zoom lens attached to a JVC KY-75U 3-CCD digital video camera that feeds image data to a desktop computer. The stacks of pictures produced with CARTOGRAPH were combined into a fullfocus image with COMBINEZM (http://www.hadleyweb.pwp.blueyonder.co.uk/ $\mathrm{CZM} /$ combinezm.htm). All images are also available at www.morphobank.org. The respective accession numbers are indicated in the legends of the figures.

Morphological terminology follows Carmean and Kimsey (1998), as adapted from Gauld and Bolton (1988). The hypoepimeron, and the scrobal sulcus which delimits it ventrally, are used here in the same sense as the "hypoepimeral area" and the "scrobal suture", respectively, of Richards (1956). Surface sculpture terminology follows Harris (1979). Genus-level identifications were performed with the key provided by Carmean (2006). All specimens are deposited in the collections of Universidade Federal do Espirito Santo (UFES) or CEPLAC.

\section{Results and discussion}

A total of 65 specimens of Trigonalidae were collected. Three species of Trigonalys Westwood were recognized: T. melanoleuca Westwood, and two new species, described below. Most specimens were collected in November, probably because of the higher sampling effort in that month. Specimens were however collected throughout the year, in January, February, April, June, August, November, and December.

The numbers of specimens collected in these events are unusual compared with the well-known rarity of Trigonalidae in general. These wasps have been consistently difficult to obtain in all collecting trips performed by the authors in all major Brazilian ecosystems. Additional evidence to this observation is the absence of trigonalid specimens in most inventory-driven projects (e.g., Noyes 1989, Azevedo et al. 2003, Perioto et al. 2005). Our observations suggest that the usual capture success for Malaise traps, lies around one specimen for each 1,000-2,000 trap-days. The capture success in the cacao agroforestry system, however, yielded an impressive ratio of one specimen for each 98 trap-days, which is about 10 to 20 times higher than expected. Murphy et al. 2009 report the capture of hundreds of specimens in North America, but the high success of capture reported here seems to be an unique record for South America.

Table I. Number of specimens of Trigonalidae (Hymenoptera) collected in a cacao agroforestry system in southeastern Brazil, with totals for each species, for females, males, and total, followed by the corresponding male/female sex ratio ( $m / f$ Ratio).

\begin{tabular}{l|l|l|l|l}
\hline Species & Females & Males & Total & m/f Ratio \\
\hline T. melanoleuca Westwood & 13 & 28 & 45 & 2.15 \\
\hline T. gotica sp. n. & 8 & 10 & 18 & 1.25 \\
\hline T. erythrocephala sp. n. & 2 & 0 & 2 & - \\
\hline
\end{tabular}


The reasons for this unexpectedly high abundance, in this particular environment, have not been investigated. One possibility, however, is that the high concentration of cacao trees might have contributed to maintain high levels of directly or indirectly associated populations of suitable hosts.

\section{Taxonomy}

\section{Trigonalys melanoleuca Westwood}

http://species-id.net/wiki/Trigonalys_melanoleuca

Figs $1-2$

Trigonalys melanoleuca Westwood 1835:53. Lectotype $\odot$, designated by Carmean and Kimsey (1998), Brazil (BMNH, not examined)

Diagnosis. Black with whitish marks; mesopleuron with large white mark placed just ventrad to scrobal sulcus; legs with extensive white marks; propodeum and metasoma with extensive whitish or yellow marks. Fore wing distinctly infuscated, much darker centrally and antero-apically; metasomal armature absent, posterior margin of tergum I rounded (Fig. 2); propodeum uniformly punctate; propodeal foramen shaped as an inverted U.

Material examined. 13 우, 28 ๙ิฮิ. BRAZIL, Bahia, Malaise trap, JCardoso \& JMaia. 1 ㅇ, Barra do Rocha, Fazenda Iacina, Pt. 1, 19.XI.2002. 3 $\widehat{\jmath}$, Buerarema, Fazenda Boa Sorte, Pt. 3, 29.XI.2002; 1 ऊ, same data except Pt. 4; $4 \hat{\delta} \delta^{\lambda}$, same data

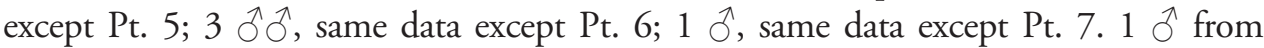
Ilhéus, CEPLAC/ESOMI, Borda, Pt. 2, 8.VIII.2001. 1 q, Ipiaú, Fazenda Afegan, Pt. 2, 21.XI.2002. 1 ô, Itacaré, Fazenda Muchirão, Pt. 1, 22.XI.2002; 1 + , same data except Pt. 7, 9.IV.2003. 1 9, Itororó, Fazenda Bela Vista, Pt. 8, 15.XII.2003 (UFES). 1 O̊, Ubaitaba, Fazenda Casa de Pedra, Pt. 1, 9.IV.2003; 1 ठ, same data except Pt. 3; 1 + , same data except Pt. 4, 13.XII.2003; 1 \%, same data except Pt. 5, 16.VIII.2002; 1 ${ }^{\top}$, same data except 9.IV.2003; 1 ㅇ $1 \hat{\jmath}$, same data except Fazenda Fortaleza, pt. 1, 16.VIII.2002; 1

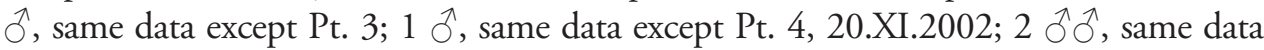
except XII.2003; 1 ㅇ $6 \hat{\delta} \hat{\partial}$, same data except Pt. 5, 20.XI.2002; 1 ते, same data except 15.VI.2003; 1 , same data except Pt. 6; 1 ${ }^{\lambda}$, same data except 13.XII.2003; 1 + , same data except Pt. 8, 9.IV.2003. 1 Oे, Uruçuca, Fazenda Bom Jardim, 12.IV.2003; 1 q, same data except Pt. 2, 23.XI.2002; 1 §ै, same data except 9.XII.2003 (CEPLAC); 1 , same data except Pt. 4, 23.XI.2002; 1 \%, same data except Pt. 8 (UFES).

Comments. Trigonalys melanoleuca was one of the first trigonalid species to be described. It may be the most commonly collected species of the family in the Neotropics. In spite of that, its hosts are still unknown. The examined specimens exhibit substantial intraspecific variation, particularly the wing venation. This high variation, however, seems to be the rule for Trigonalidae as a whole (Carmean and Kimsey 1998). 


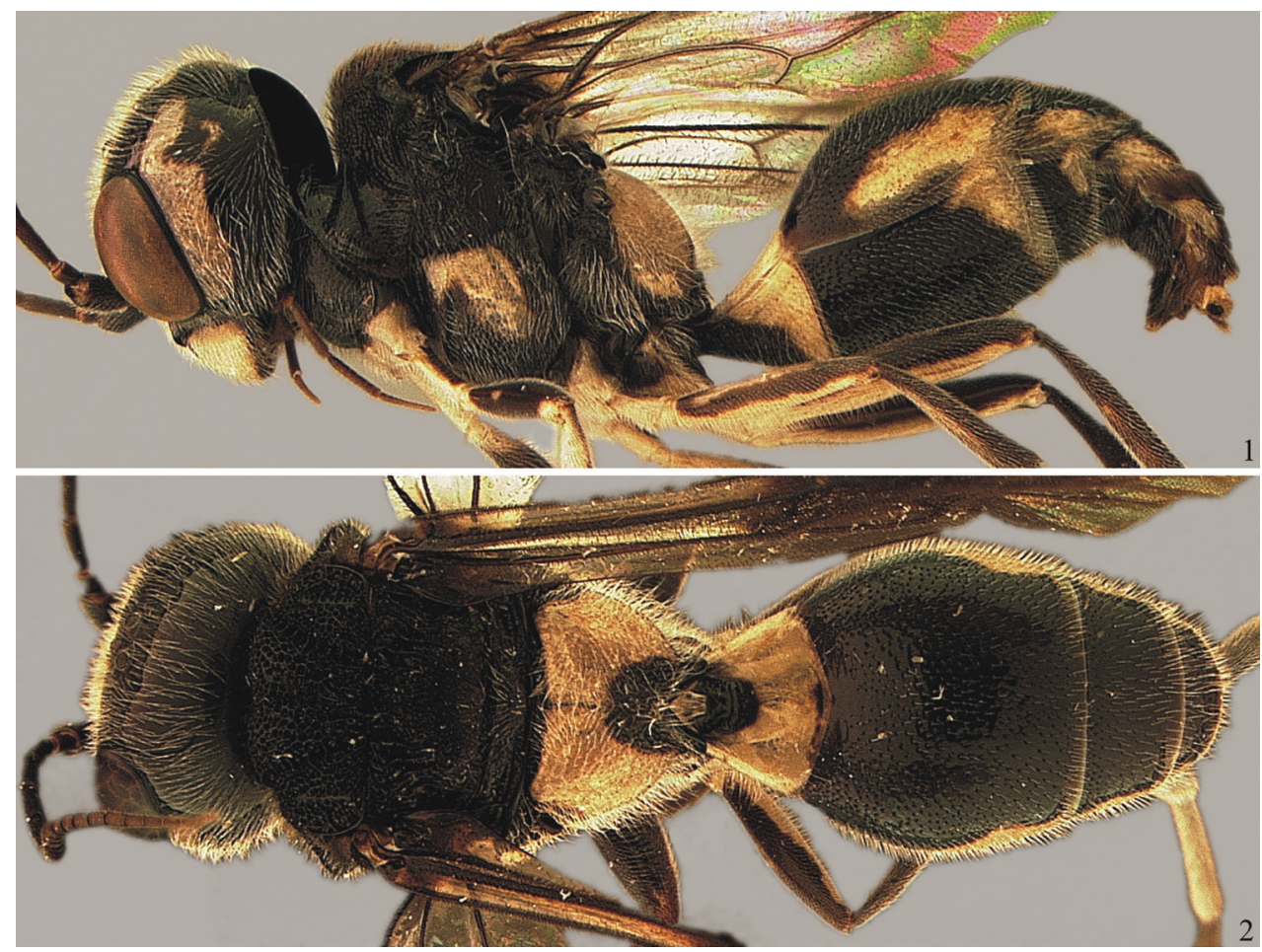

Figures I-2. Trigonalys melanoleuca Westwood. I Lateral habitus. Morphobank accession number (M99947) 2 Dorsal habitus. Morphobank accession number (M99948)

\section{Trigonalys erythrocephala Santos \& Aguiar, sp. n.}

urn:Isid:zoobank.org:act:BB34085C-A5DE-4DEB-98D4-71FDD83E7FE4

http://species-id.net/wiki/Trigonalys_erythrocephala

Figs $3-12$

Holotype ${ }_{+}$, Brazil, Bahia, Uruçuca, Fazenda Bom Jardim, Pt 5, 25.XI.2002, Malaise trap, J. Cardoso \& J. Maia (UFES). Mounted on a triangle point; in good condition.

Paratype $\odot$, same data as holotype, except Pt 7, 23.XI.2002 (CEPLAC).

Diagnosis. Frons, most of vertex, and temple, reddish brown; metasomal armature of sternum III conspicuous, Y-shaped; supra-antennal elevation stout, conspicuous; hind coxa dorsally somewhat concave longitudinally, forming two longitudinal edges on each side, throughout its length, dorso-mesal portion strigate; legs entirely dark brown; fore wing nearly uniformly infuscate, except slightly darker along anterior margin.

Description. Holotype: body length $8.5 \mathrm{~mm}$; fore wing length $7.4 \mathrm{~mm}$.

Head (Figs 1, 2-4). Mandible covered with long and moderately dense setae; ventral tooth of right mandible distinctly longest and narrowest, median teeth length subequal, [dorsal tooth not visible; mandibles closed, left mandible not observed]. 

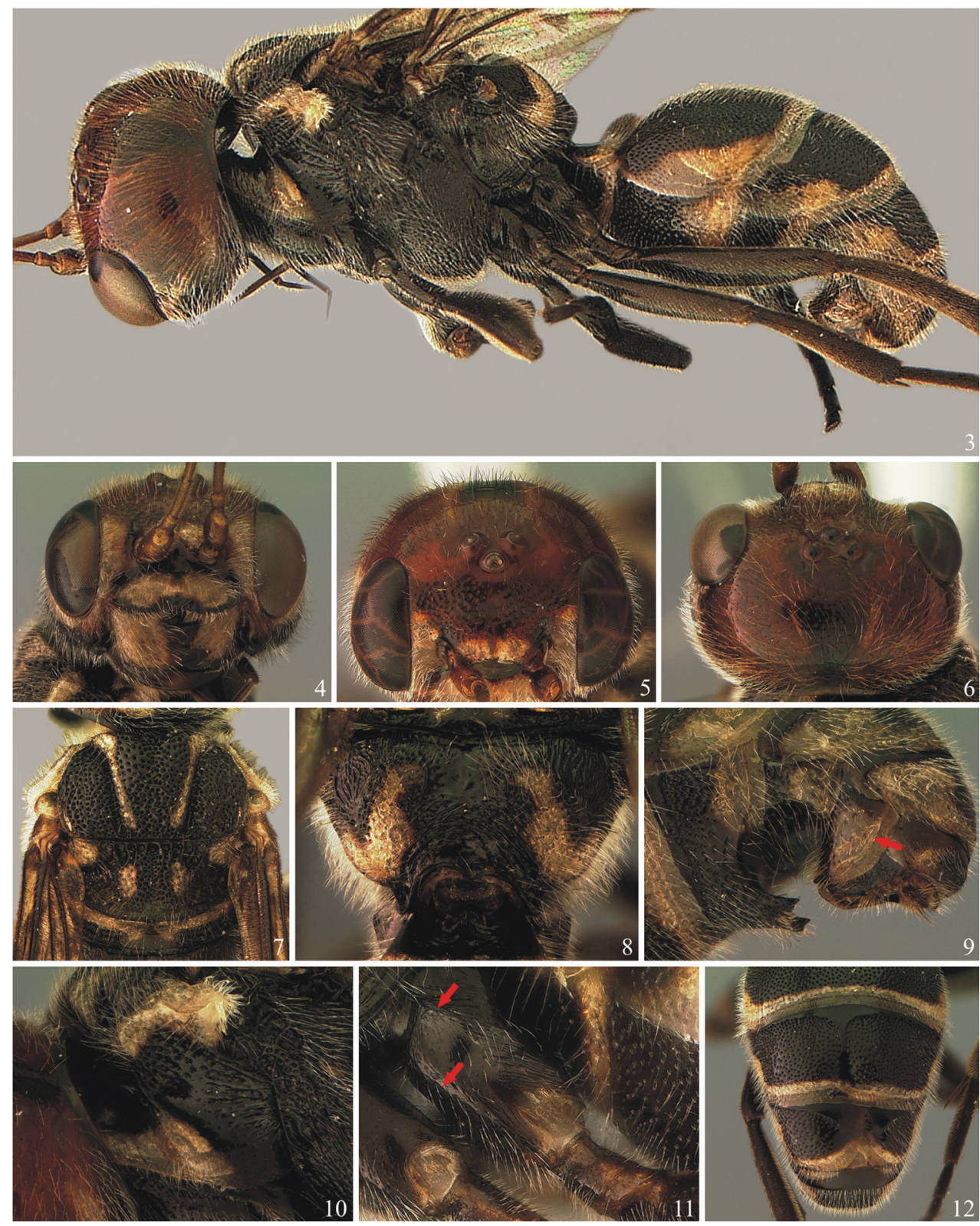

Figures 3-12. Trigonalys erythrocephala Santos et Aguiar, sp. n. Holotype female. 3 Lateral habitus (Morphobank accession number M90448) 4 Head, antero-ventral (M90449) 5 Head, antero-dorsal, to show ocelli (M90450) 6 Head, dorsal (M90451) 7 Mesothorax, dorsal (M90452) 8 Propodeum and base of petiole, dorsal (M90453) 9 Apical segments of metasoma, latero-ventral, left, showing metasomal armature and ovipositor; arrow indicates position of longitudinal carina (M90454) 10 Pronotum, left (M90455) I I Left hind coxa, to show lateral longitudinal carinae (arrows) and dorso-mesal strigation (M90456) I 2 Apical tergites, to show abnormal development of tergites (M90457). 
Clypeus $2.28 \times$ as wide as maximum length, laterally distinctly pilose, centrally glabrous, faintly punctate. Inner margin of eyes subparallel; interocular distance at narrowest level $1.17 \times$ maximum eye height. Antenna with 25 flagellomeres, about $1.4 \times$ the lateral length of mesosoma; intertoruli distance slightly longer than distance from torulus to inner margin of eye. Supra-antennal elevation conspicuous, laterally a sharp carina (Fig. 5), between antennae with rounded border. Frons pilose, densely punctate; punctation at median portion dorsally sparse, feeble; frons medially with a subtle longitudinal depression; area around and between ocelli slightly concave (Fig. 5). Vertex shiny, densely pilose, moderately punctate. Gena maximum width in lateral view $0.83 \times$ maximum eye height, finely punctate, densely pilose, particularly at ventral 0.4. Occipital carina conspicuous, widest dorsally, narrowest ventrally.

Mesosoma (Figs 3, 7-8). Densely pilose. Pronotum: anterior, neck-shaped portion moderately long, laterally transversally wrinkled (Fig. 3), centrally distinctly concave, anterior margin wide, polished; pronotum lateral area dorsally densely punctate, ventrally sparsely punctate, its posterior margin with distinct longitudinal wrinkles; central portion of lateral area intensely concave, anteriorly with stout oblique carina (Fig. 10). Mesoscutum and scutellum deeply punctate (Fig. 7), almost punctate-reticulate; notaulus deeply impressed, with distinct transverse wrinkles inside; median lobe of mesoscutum progressively raised from lateral lobes, until quite detached at anterior end; median lobe and scutellum with shallow but distinct mid-longitudinal sulcus; scutellum anteriorly with distinct longitudinal crenulation, centrally distinctly projected, subpyramidal; posterior margin shiny and impunctate. Hypoepimeron distinctly projected, subpyramidal, punctate, except small posterior area shiny and impunctate; scrobal sulcus distinct, somewhat crenulate; mesopleuron otherwise mostly punctate to areolate-punctate. Mesopleural suture dorsally deeply carinate. Metanotum (a narrow yellow stripe; Fig. 7) anteriorly moderately punctate, posteriorly impunctate; metapostnotum (the subsequent black stripe) rugose. Metapleuron finely punctate. Transverse sulcus at base of propodeum as long as metapostnotum, shallow, finely crenulate (Fig. 8). Propodeum densely pilose, laterally setae distinctly longer than centrally; antero-lateral corners longitudinally rugose, otherwise mostly punctate-areolate or areolate-rugose, centrally and posteriorly in concentric patterns, anteriorly with shiny and almost impunctate area; propodeal spiracle covered by prominent, tubercle-like flap. Propodeal foramen somewhat Mshaped (Fig. 8). Hind coxa with two sharp lateral angles extending throughout its length (Fig. 11), dorso-mesal portion strigate.

Wings. Fore wing vein $\mathrm{M}$ arising almost opposite to crossvein $1 \mathrm{cu}-\mathrm{a}$; crossvein $2 \mathrm{~m}$ $\mathrm{cu}$ distinctly sinuous, with bulla on anterior 0.75 ; crossveins $2 \mathrm{r}-\mathrm{m}$ and $3 \mathrm{r}-\mathrm{m}$ almost straight. Second submarginal cell distinctly petiolate; third submarginal cell subtrapezoidal, slightly wider than high.

Metasoma. Densely covered with short setae. Tergum I slightly concave, short and broad, trapezoidal in dorsal view; $0.45 \times$ as long as maximum width, apical width 
$1.48 \times$ basal width; mid-basally with a few distinct, somewhat concentric rugulosities; posterior margin nearly straight across, with large but shallow punctures. Terga II-V and sterna I-V densely punctate, densely covered with short setae. Metasomal armature developed on sternum III as single, Y-shaped, very sclerotinized projection, with pointed corners (Fig. 9). Ovipositor sheath shaped as a curved beak, laterally with longitudinal carina (Fig. 9).

Color. Head mostly reddish brown, body mostly black, with yellowish marks. Head: antenna basally ferruginous, otherwise brown or nearly so; palpi dark brown; ventral margin of mandible, teeth apex, clypeal borders, small marks dorsad to toruli, subtriangular mark on vertex and most of gena and occiput, black; mandible except apex, clypeus, area around ventral 0.7 of eye and small marks on gena and around subtriangular black area, pale yellow; subapical portion of mandible between yellow and black areas, frons, most of vertex, and area around dorsal 0.3 of eye, reddish brown; vertex with dark, triangular mark behind ocelli, extending and narrowing posteriorly until it reaches occipital carina; a yellow stripe along each side of dark triangle. Mesosoma: black, except pale yellow to yellow on pronotal collar, dorsal margin of pronotum, margins of median mesoscutal lobe, alongside notaulus, lateral longitudinal marks on scutellum, axilla, metanotum, small central spot on mesopleuron, on apex of pyramidal projection, and J-shaped mark on each side of propodeum. Prominence of propodeal spiracle ferruginous. Legs apically to coxae dark brown. Wings slightly infuscate, fore wing darker towards anterior margin. Metasoma: black; all terga and sterna with posterior pale yellow stripes, on terga II-V also extending laterally; tergum VI brownish; sternum $\mathrm{V}$ almost entirely pale yellow.

Male. Unknown.

Variation. Holotype with terga II-IV showing anomalous development (Fig. 12). Paratype body length $9.3 \mathrm{~mm}$; fore wing length $7.7 \mathrm{~mm}$; yellow marks on gena and near subtriangular black mark at vertex, very subtle; propodeum anteriorly more distinctly sculptured, without shiny and almost impunctate area; propodeal foramen Ushaped; second submarginal cell less distinctly petiolate.

Comments. In terms of general morphology, this species is closest to T. melanoleuca, from which it can be readily differentiated by its color pattern, with frons, most of vertex, and part of gena, reddish brown (vs. black with whitish marks, without reddish brown areas in T. melanoleuca); yellow marks at pronotal collar, dorsal margin of pronotum, mesoscutum, scutellum, and metanotum (vs. marks absent); yellow mark at mesopleuron very small and placed dorsad to longitudinal sulcus (vs. large, placed ventrad to sulcus); legs entirely dark brown (vs. with extensive white marks); and yellow marks on propodeum and metasoma less extensive than in T. melanoleuca. Additionally, T. melanoleuca has the fore wing more distinctly infuscated, metasomal armature absent, posterior margin of tergum I rounded (vs. nearly straight), propodeum uniformly punctate (vs. laterally areolate, anteriorly coriarious and posteriorly striate) and propodeal foramen always shaped as an inverted U (vs. U- or M-shaped).

The color pattern of T. erythrocephala is more similar to that of $T$. gotica, which is also mostly blackish with yellow marks on the pronotal collar, dorsal margin of 
pronotum, mesoscutum, scutellum, and metanotum. However, the two species differ markedly in general structure. Trigonalys gotica has a subtle supra-antennal elevation (vs. stout, conspicuous in T. erythrocephala); vertex deeply punctate-areolate (vs. moderately punctate); pronotal collar very slightly raised (vs. moderately raised), pronotum with a less evident oblique carina; hind coxa laterally with slight, blunt angles and without strigate area; propodeal foramen V-shaped (vs. U- or M-shaped), and female armature absent (vs. well developed).

$T$. erythrocephala can be differentiated from $T$. sanctaecatharinae mainly by the distinct, Y-shaped female armature (vs. delicate, not distinctly Y-shaped) and by the quite different color pattern (Figs 3, 20).

It can also be distinguished from the other New World species of Trigonalys as follows. Both T. flavescens Bischoff and T. maculifrons Sharp have an elongate body, resembling species of Orthogonalys Schulz. Both are also mostly yellow or orange with black marks, including the head yellow with black marks on frons (vs. reddish, without black marks at frons); scutellum yellow with posterior black mark (vs black with sublateral, narrow yellowish lines) and legs mostly yellow (vs. black and dark brown); basal third of tergum I dark brown and remainder yellow (vs. tergum I basal 0.7-0.8 black, apically yellowish). Trigonalys championi Cameron, has the antenna entirely black (vs ferruginous to brown); frons, vertex and gena black (vs. mostly reddish); fore wing entirely violaceous (vs. slightly infuscate, darker at anterior margin); propodeum and petiole mostly whitish (vs. propodeum black with sublateral narrow yellowish marks, petiole mostly black with apical $0.2-0.3$ yellowish); and other metasomal segments entirely black (vs. with extensive yellowish marks).

Etymology. From the Greek erythros, red, and cephalon, head, in reference to the somewhat characteristic color of the head capsule.

\section{Trigonalys gotica Santos \& Aguiar, sp. n.}

urn:1sid:zoobank.org:act:2797E8BF-8824-4875-AE58-0AD9E5547B3B

http://species-id.net/wiki/Trigonalys_gotica

Figs 13-19

Holotype 9 , Ubaitaba, Fazenda Casa de Pedra, Pt. 5, 20.XI.2002 (UFES).

Paratypes. 1 q , Barra do Rocha, Fazenda Iacina, Pt. 1, 19.XI.2002. 1 đ̊, Buerare-

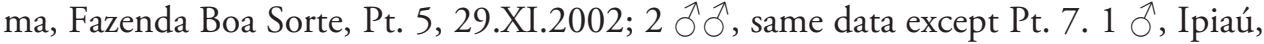
Fazenda Petrolina, Sítio Casca, Oeste, 15.II.2007. 1 9, Itacaré, Fazenda Muchirão, Pt. 1, 22.XI.2002; 1 đ̆, same data except Pt. 2, 12.XII.2003. 1 q, Itororó, Fazenda Santa Cruz, pt. 3, 24.XI.2002 (UFES); 1 đ̋, same data except Pt. 7, 24.VIII.2003. 1 ๆ from Ituberá, Fazenda Vale da Juliana, Leste, 26.I.2007. 1 ふ̋, Ubaitaba, Fazenda Casa de Pedra, Pt. 5, 9.IV.2003; 1 ふै, same data except Fazenda Fortaleza, pt. 1, 16.VIII.2002; 1 q, same data except Pt. 4; 1 , same data except XII.2003; $1 \hat{\jmath}$, same data except Pt. 7, 20.XI.2002; 1 q, same data except Pt. 8, 16.VIII.2002. 1 đ̊, Uruçuca, Fazenda Bom Jardim, Pt. 4, 23.XI.2002 (CEPLAC). 


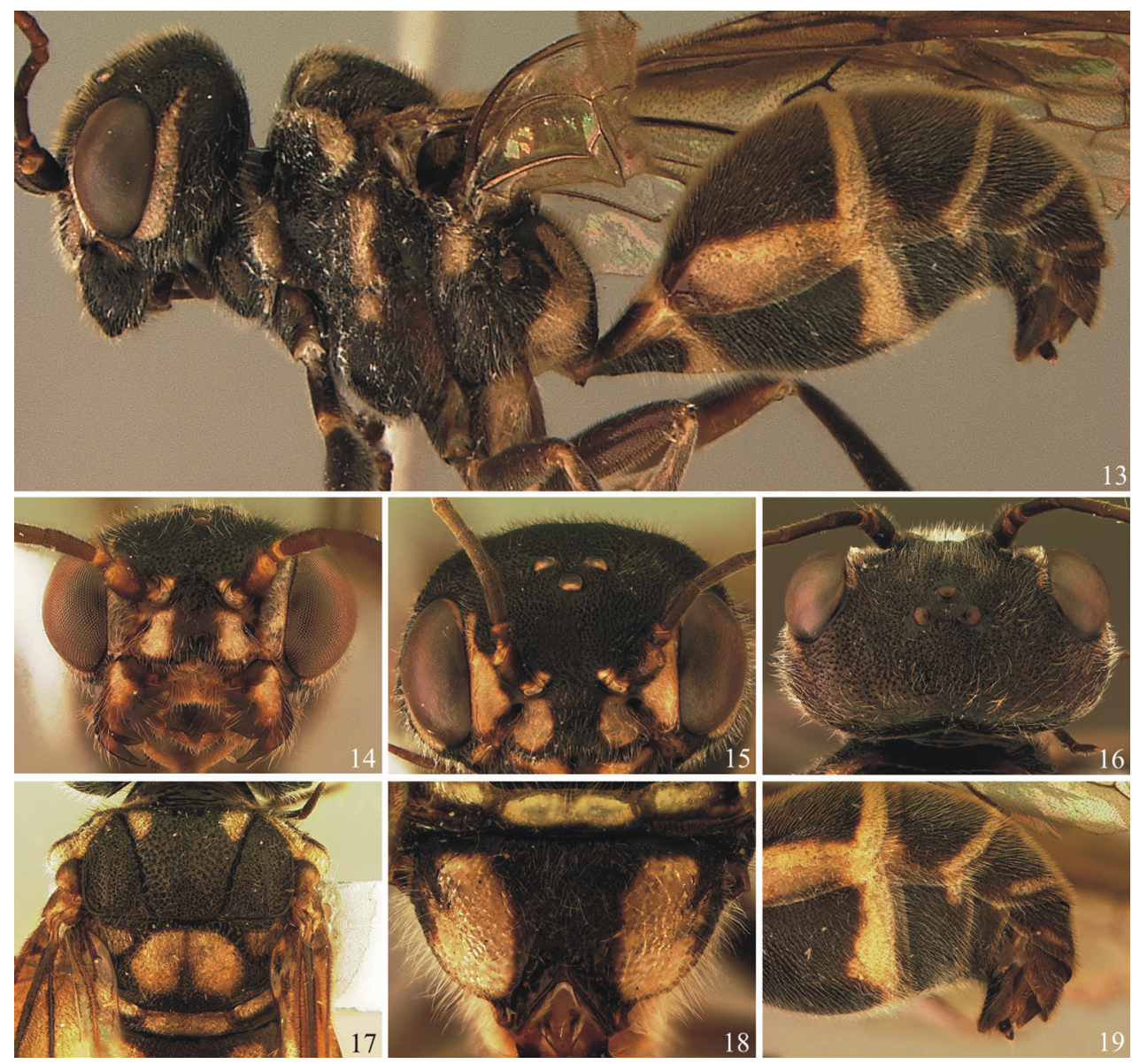

Figures 13-19. Trigonalis gotica Santos et Aguiar, sp. n. Holotype female except Figure 14. 13 Lateral habitus (Morphobank accession number M99940) I4 Paratype female, head, antero-ventral (M99941) 15 Head, antero-dorsal (M99942) I 6 Head, dorsal (M99943) I7 Mesothorax, dorsal (M99944) I 8 Propodeum, dorsal (M99945) 19 Apical segments of metasoma, latero-ventral, left, showing ovipositor (M99946).

Diagnosis. Blackish or dark brown with pale yellow marks; mesopleuron with oblique mark extending from dorsad to ventrad of longitudinal sulcus; female armature absent; frons and vertex punctate-areolate; supra-antennal elevation subtle; propodeal foramen $\mathrm{V}$-shaped; fore wing vein $\mathrm{M}$ arising distinctly basad to crossvein 1cu-a.

Description. Holotype: body length $9.9 \mathrm{~mm}$; fore wing length $9.0 \mathrm{~mm}$.

Head (Figs 13, 14-16). Mandible covered with dense and moderately long setae, teeth glabrous; four teeth on right mandible; dorsal tooth of right mandible [observed in paratypes; right mandible of holotype not visible] slightly longer than median teeth, distinctly bent upwards; ventral tooth slightly longer and more slender than other teeth; three teeth on left mandible, dorsal tooth dorsally pointed and bent, ventrally round, sharp, ventral tooth slender, pointed, median tooth intermediate between dor- 
sal and ventral (Fig. 14). Clypeus $2.60 \times$ as wide as maximum length, densely pilose, deeply punctate. Inner margin of eyes subparallel; interocular distance at narrowest level $1.36 \times$ maximum eye height. Antenna with 23 flagellomeres, about twice the lateral length of mesosoma; intertoruli distance distinctly longer than distance from torulus to inner margin of eye. Supra-antennal elevation subtle, not forming a sharp carina. Frons and vertex densely covered with short hairs, entirely deeply punctateareolate; frons without any trace of longitudinal depression; posterior ocelli slightly turned laterally so that they are weakly elevated medially while forming a small depression on vertex laterally. Gena width in lateral view, at level of midline of eye, $1.25 \times$ maximum eye height, moderately punctate, densely pilose, particularly at ventral 0.4 . Occipital carina conspicuous, slightly widest dorsally.

Mesosoma (Figs 13, 17-18). Densely pilose. Pronotum: anterior, neck-shaped portion short, in dorsal view transversal, about $3.6 \times$ as wide as long, crossed anteriorly by single, stout, transverse carina, centrally nearly smooth, anterior margin sharp, reflexed upwards; a line of tall, erect hairs along anterior margin and another line of same hairs along anterior carina; pronotum lateral area dorsally subareolate-rugulose, ventrally sparsely to densely punctate, its posterior margin with longitudinal wrinkles; central portion of lateral area intensely concave, anteriorly with distinct oblique swelling. Mesoscutum and scutellum foveate-areolate, centrally more coarsely; lateral lobe with narrow, straight, smooth, mid-longitudinal line; notaulus deeply impressed, with a few transverse wrinkles inside; median lobe of mesoscutum progressively raised from base to apex, until moderately detached from lateral lobes at anterior end; scutellum with very shallow but distinct mid-longitudinal sulcus; mesosoma crenulated along its entire width just behind transscutal articulation. Hypoepimeron distinctly projected, subpyramidal, punctate, except small posterior area shiny and impunctate; scrobal sulcus distinct, somewhat crenulate; mesopleuron otherwise mostly punctate to areolatepunctate. Mesopleural suture entirely carinate. Metanotum (a narrow yellow stripe; Fig. 17) with only a few anterior punctures. Metapleuron areolate-rugulose. Transverse sulcus at base of propodeum very narrow, moderately deep. Propodeum densely pilose, laterally setae slightly longer and erect than centrally; areolate-rugulose, laterally more coarsely, medially with very slight longitudinal line, sublaterally with raised lines (perhaps traces of longitudinal carina); propodeal spiracle covered by prominent, convoluted flap. Propodeal foramen shaped as an acute, inverted V. Legs covered with dense whitish pubescence; hind coxa moderately punctate, dorsally with distinct, wide depression, deepest at apex (probably to receive the trochanters).

Wings. Fore wing vein $\mathrm{M}$ arising distinctly basad to crossvein $1 \mathrm{cu}-\mathrm{a}$; crossvein $2 \mathrm{~m}$ $\mathrm{cu}$ distinctly sinuous, with bulla on anterior 0.65 ; crossveins $2 \mathrm{r}-\mathrm{m}$ and $3 \mathrm{r}-\mathrm{m}$ almost straight. Second submarginal cell not petiolated; third submarginal cell subrectangular, much wider than high.

Metasoma (Fig. 19). Densely and fully covered with short setae. Tergum I short and broad, trapezoidal in dorsal view, $1.63 \times$ as long as its maximum width, apical width $2.80 \times$ basal width, centrally distinctly concave and with slight transverse wrinkles, tergum otherwise impuctate; posterior margin nearly straight across. Terga II-V 
and sterna I-V areolate, densely covered with short setae. Metasomal armature absent. Ovipositor sheath conical, without carinae.

Color. Blackish with pale yellow marks. Head: blackish; antenna mostly dark brown, except flagellomeres 4-8 or so brown, and last 6 apical flagellomeres progressively lighter, last one yellowish brown; palpi brown; dorsal mark on mandible, part of malar space, lateral areas of clypeus and face, small mark on inner margin of torulus, and narrow mark on gena along most of eye length, pale yellow. Mesosoma: mostly blackish, pale yellow on pronotal collar, dorsal margin of pronotum, median mesoscutal lobe antero-laterally on each side, along anterior third of notaulus, axilla almost entirely, scutellum except posterior margin and mid-longitudinally, metanotum, nearly vertical stripe on mesopleuron, metapleuron just ventrad of hind wing, posterior 0.6 of metapleuron and contiguous with sublateral mark on propodeum; shiny brownish on tegula and prominence of propodeal spiracle. Legs mostly dark brown, fore tibia anteriorly mostly yellow, hind trochanters fully and coxa dorsally yellowish. Wings slightly infuscate, fore wing widely infuscate in brown along entire anterior margin. Metasoma: blackish; terga I-V and sterna I-II with posterior margin bearing a narrow pale yellow stripe, on terga II-III stripe also extending longitudinally along ventral margin; tergum VI brownish; sterna III-IV at apical margin with small lateral pale yellow marks.

Male. Essentially identical to female, except by genital features. Antenna with 20-22 flagellomeres.

Variation. Body 5.0-9.9 mm long, small to medium-sized specimens, observed both for males and females; fore wing 5.0-9.0 mm long. Antenna with 20-23 flagellomeres. In many specimens the blackish areas are brownish; some specimens with bright yellow marks instead of pale yellow. Scutellum almost entirely yellow or having slight to distinct posterior blackish mark. Crossvein $2 \mathrm{~m}$-cu sometimes only slightly sinuous; second submarginal cell may vary from nearly to distinctly (but shortly) petiolate. Small specimens have lighter/paler color tonalities than large ones.

Comments. This species does not match any of the described New World species of Trigonalys. It can be readily differentiated from $T$. sanctaecatharinae (Schulz) by the absence of female armature ( $v$ s. present, though delicate, on sternum III, on $T$. sanctaecatharinae). The color pattern of the two species is also almost entirely different (Figs 13, 20). It is however important to mention that "melanic" forms are known for T. sanctaecatharinae that are more extensively black. Further differences include the vertex areolate-rugulose (vs. punctate in T. sanctaecatharinae); anterior, neck-shaped portion of pronotum short (vs. quite long); central lobe of mesoscutum only subtly elevated (vs. distinctly elevated, detached from lateral lobes); and longitudinal groove on mesopleuron straight (vs. curved upwards).

It is distinguished from T. melanoleuca by the color pattern, with yellow marks on pronotal collar, dorsal margin of pronotum, mesoscutum, scutellum, and metanotum (vs. marks on those areas absent in T. melanoleuca); mesopleuron with an oblique mark extending from dorsad to ventrad of longitudinal sulcus (vs. with large mark placed ventrad to sulcus); mid and hind femora predominantly dark brown (vs. often with 


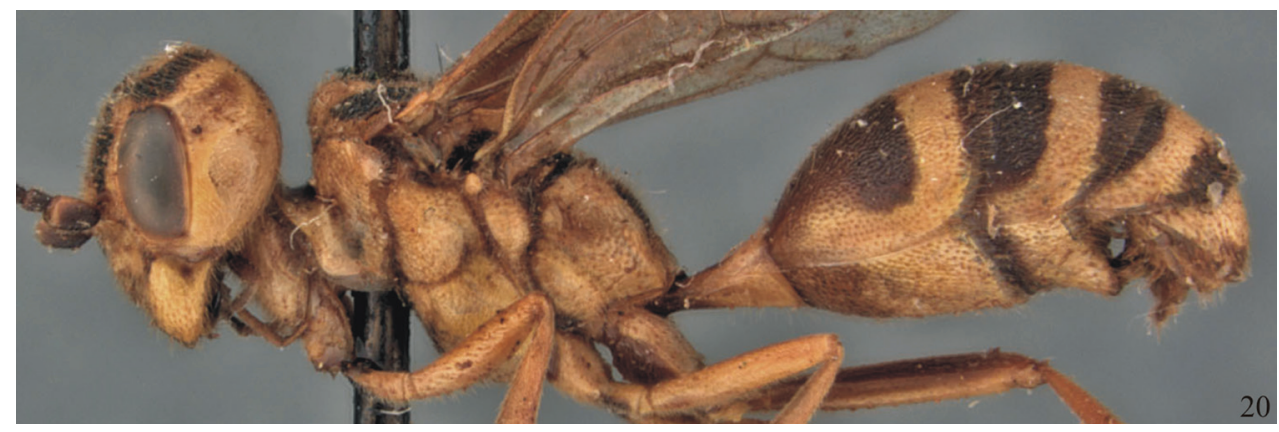

Figure 20. Trigonalys sanctaecatharinae (Schulz), lateral habitus (Morphobank accession number M99949). Picture by David Smith (NMNH).

extensive white marks). Additionally, T. melanoleuca has the fore wing more distinctly infuscate centrally (cells 1R1, 1M, 2Cu, 1Rs) and antero-apically (cells 2R1, 2Rs) (vs. infuscated along entire anterior margin only), supra-antennal elevation very stout, vertex sculpturing smooth (vs. coarse punctate-areolate), propodeum uniformly punctate (vs. areolate-rugulose) and posterior margin of tergum I rounded (vs. nearly straight).

The color pattern of $T$. gotica is more similar to that of $T$. erythrocephala (see above), but the two species can be easily differentiated by their general structure. Trigonalys gotica has subtle supra-antennal elevation (vs. stout, conspicuous in T. erythrocephala); vertex deeply punctate-areolate (vs. shiny, finely punctate); pronotal collar very slightly raised (vs. moderately raised), pronotum with a less evident oblique carina (vs. distinct); hind coxa without distinctly deep depression to receive trochanters (vs. distinctly deep); propodeal foramen V-shaped (vs. U- or M-shaped), and female armature absent (vs. well developed).

The diagnostic differences provided above to separate T. erythrocephala from the remaining New World species of Trigonalys (T. flavescens, T. championi and T. maculifrons) also apply equally well to distinguish them from $T$. gotica.

Etymology. The specific epithet refers to the shape of the petiolar foramen, which reminds the classic design of a Gothic arch.

\section{Acknowledgements}

David Carmean (Simon Fraser University, Burnaby, BC, Canada) kindly helped with the literature and provided drafts of identification keys from his own work with Trigonalidae. Maria-Julia O. Valverde and Jacques H. C. Delabie (CEPLAC) received BFS and AMT in a scientific visit, allowing full access to the material collected by the CEPLAC team, and generously donated all relevant specimens to UFES. Celso Azevedo (UFES) and Kazuiyuki Nakayama (CEPLAC) designed the sampling protocol of the collecting trips. David Carmean (Simon Fraser University) kindly helped with literature, suggestions and old drafts of keys. David R. Smith (NMNH), Wojciech Pulawski 
(CASC) and two anonymous reviewers revised the original manuscript, contributing with important suggestions. Dave also provided digital pictures of a cotype of Xanthogonalos fasciatus Bertoni $(=T$. sanctaecatharinae). One of the anonymous reviewers kindly provided pictures of T. championi, T. flavescens and T. maculifrons. This work benefitted from research funding from FAPES - Fundação de Amparo à Pesquisa do Espirito Santo, to Alexandre P. Aguiar (Process 45.440.611/2009).

\section{References}

Azevedo CO, Corrêa MS, Gobbi FT, Kawada R, Lanes GO, Moreira AR, Redighieri ES, Santos LM, Waichert C (2003) Perfil das famílias de vespas parasitóides em uma área de Mata Atlântica da Estação Biológica de Santa Lúcia, Santa Teresa, ES, Brasil. Boletim do Museu Biológico Mello Leitão (Nova Série) 16: 39-46.

Cameron P (1897) New species of Hymenoptera from Central America. Annals and Magazine of Natural History 6(19): 261-276, 368-379. doi: 10.1080/00222939708680536

Carmean D (1991) Biology of the Trigonalyidae (Hymenoptera), with notes on the vespine parasitoid Bareogonalos canadensis. New Zealand Journal of Zoology 18: 209-214.

Carmean D (2006) 8.3. Família Trigonalidae. In: Hanson PE, Gauld ID (Eds) Hymenoptera de la Región Neotropical. Memoirs of the American Entomological Institute 77: 212-216.

Carmean D, Kimsey L (1998) Phylogenetic revision of the parasitoid wasp family Trigonalidae. Systematic Entomology 23: 35-76. doi: 10.1046/j.1365-3113.1998.00042.x

Dall'Oglio OT, Zanuncio JC, Azevedo CO, Medeiros AGB (2000) Survey of the Hymenoptera Parasitoids in Eucalyptus grandis and in a Native Vegetation Area in Ipaba, State of Minas Gerais, Brazil. Anais da Sociedade Entomológica do Brasil 29(3): 583-588. doi: 10.1590/S0301-80592000000300021

Gauld ID, Bolton B (1988) The Hymenoptera. British Museum (Natural History) and Oxford University press, Oxford.

Harris RA (1979) A glossary of surface sculpturing. Occasional Papers in Entomology 28: $1-31$.

Murphy SM, Lill JT, Smith DR (2009) A scattershot approach to host location: uncovering the unique life history of the trigonalid hyperparasitoid Orthogonalys pulchella (Cresson). American Entomologist 55(2): 82-87.

Nakayama K, Azevedo CO, Valverde MJ, Neves FS, Sperber CF (2008) Sampling parasitoid wasps (Insecta, Hymenoptera) in cacao agroforestry systems. Studies on Neotropical Fauna and Environment 43: 217-226. doi: 10.1080/01650520802019404

Noyes JS (1989) A study of five methods of sampling Hymenoptera (Insecta) in a tropical rainforest, with special reference to the Parasitica. Journal of Natural History 23: 285-298. doi: $10.1080 / 00222938900770181$

Perioto NW, Lara RIR, Santos JCC, Selegatto A (2002a) Himenópteros parasitóides coletados em cultura de algodão (Gossypium hisurtum L.) (Malvaceae) no município de Ribeirão Preto, SP, Brasil. Revista Brasileira de Entomologia 46(2): 165-168. doi: 10.1590/S008556262002000200008 
Perioto NW, Lara RIR, Santos JCC, Silva TC (2002b) Himenópteros parasitóides coletados em cultura de soja (Glycine $\max (\mathrm{L})$.$) Merril (Fabaceae) no município de Nuporanga, SP,$ Brasil. Revista Brasileira de Entomologia 46(2): 185-187.

Perioto NW, Lara RIR, Selegatto A, Luciano ES (2004) Himenópteros parasitóides coletados em cultura de café Coffea arabica L. (Rubiaceae) em Ribeirão Preto, SP, Brasil. Arquivos do Instituto Biológico 71(1): 41-44.

Perioto NW, Lara RIR, Selegatto A (2005) Himenópteros parasitóides da Mata Atlântica. II. Núcleo Grajaúna-Rio Verde da Estação Ecológica Juréia Itatins, Iguape, SP, Brasil. Arquivos do Instituto Biológico 72(1): 81-85.

Richards OW (1956) Hymenoptera. Introduction and Keys to Families. Handbooks for the Identification of British Insects. Vol. VI. Part I. 94 pp.

Santos MCP, Pérez-Maluf R (2010) Comunidade de parasitóides associada à cultura do café em Piatá, Chapada Diamantina, BA. Revista Ceres 57: 194-197.

Schulz WA (1910) Ein Beitrag zur Kenntnis der Lebensweise systematik und geographischen Verbreitung der Trigonaloiden. Entomologisk Tidskrift 31: 103-108.

Sharkey MJ (2007) Phylogeny and classification of Hymenoptera. Zootaxa 1668: 521-548.

Souza L, Braga SMP, Campos MJO (2006) Himenópteros parasitóides em área agrícola em Rio Claro, SP, Brasil. Arquivos do Instituto Biológico 73(4): 465-469.

Sperber CF, Nakayama K, Valverde MJ, Neves FS (2004) Tree species richness and density affects parasitoid diversity in cacao agroforestry. Basic and Applied Ecology 5: 241-251. doi: 10.1016/j.baae.2004.04.001

Townes HK (1972) A light-weight Malaise trap. Entomological News 83: 239-247.

Vinha SG, Zevallos AC, Santos OM (1983) A fase pioneira de uma sucessão vegetal secundária no sul da Bahia: estrutura e composicão da vegetação. Revista Theobroma 13: 27-34.

Westwood JO (1835) Characters of new genera and species of hymenopterous insects. Proceedings of the Zoological Society of London 3: 51-54. 